\title{
Effects of ethanol consumption and alcohol detoxification on the biomechanics and morphology the bone in rat femurs
}

\author{
J. A. D. Garcia ${ }^{a}$, A. L. T. Souza ${ }^{b}$, L. H. C. Cruz ${ }^{c}$, P. P. Marques ${ }^{d}$, J. A. Camilli, W. R. Nakagakie, \\ A. Esteves, W. C. Rossi-Juniorf, G. J. M. Fernandes, F. D. Guerra and E. A. Soares ${ }^{*}$ \\ ${ }^{\text {a} F a c u l d a d e ~ d e ~ M e d i c i n a ~ V e t e r i n a ́ r i a, ~ U n i v e r s i d a d e ~ J o s e ́ ~ d o ~ R o s a ́ r i o ~ V e l l a n o ~-~ U N I F E N A S, ~}$ \\ Rodovia MG 179, Km 0, Campus Universitário, CEP 37130-000, Alfenas, MG, Brazil \\ bEscola de Enfermagem, Universidade Federal de Alfenas - UNIFAL, \\ Rua Gabriel Monteiro da Silva, 700, Centro, CEP 37130-000, Alfenas, MG, Brazil \\ ${ }^{\mathrm{c}}$ Departamento de Ciências Biológicas, Universidade Federal de Ouro Preto - UFOP, Campus UFOP, \\ Moro do Cruzeiro, CEP 35400-000, Ouro Preto, MG, Brazil \\ dDepartamento de Bioquímica, Instituto de Biologia, Universidade Estadual de Campinas - UNICAMP, \\ Rua Monteiro Lobato, 255, Cidade Universitária Zeferino Vaz, CEP 13083-852, Campinas, SP, Brazil \\ eDepartamento de Anatomia, Instituto de Biologia, Universidade Estadual de Campinas - UNICAMP, \\ Rua Monteiro Lobato, 255, Cidade Universitária Zeferino Vaz, CEP 13083-970, Campinas, SP, Brazil \\ fDepartamento de Anatomia, Instituto de Biociências, Universidade Federal de Alfenas - UNIFAL, \\ Rua Gabriel Monteiro da Silva, 700, Centro, CEP 37130-000, Alfenas, MG, Brazil \\ *e-mail: evelise.anatomia@gmail.com
}

Received: March 19, 2014 - Accepted: July 11, 2014 - Distributed: November 30, 2015

(With 2 figures)

\begin{abstract}
The objective of this study was to verify the effects of ethanol consumption and alcohol detoxification on the biomechanics, area and thickness of cortical and trabecular bone in rat femur. This was an experimental study in which 18 male Wistar rats were used, with 40 days of age, weighing $179 \pm 2.5 \mathrm{~g}$. The rats were divided into three groups ( $\mathrm{n}=06$ ): CT (control), $\mathrm{AC}$ (chronic alcoholic), DT (detoxification). After experimental procedures, the animals were euthanized by an overdose of the anesthetic and their femurs were collected for mechanical testing and histological processing. All animals did not present malnutrition or dehydration during experimentation period. Morphometric analysis of cortical and trabecular bones in rat femurs demonstrated that AC animals showed inferior dimensions and alcohol detoxification (DT) allowed an enhancement in area and thickness of cortical and trabecular bone. Material and structural properties data of AC group highlighted the harmful effects of ethanol on bone mechanical properties. The results of this study demonstrated that chronic alcoholic rats (AC) presented major bone damage in all analyzed variables. Those findings suggested that alcohol detoxification is highly suggested in pre-operative planning and this corroborates to the success of bone surgery and bone tissue repair. Thanks to the financial support offered by PROBIC - UNIFENAS.
\end{abstract}

Keywords: ethanol, rats, bone, alcoholism, detoxification.

\section{Efeitos do consumo de etanol e da desintoxicação alcóolica sobre a biomecânica e morfologia óssea em fêmur de ratos}

\section{Resumo}

O objetivo deste estudo foi verificar os efeitos do consumo de etanol e da desintoxicação alcoólica sobre a biomecânica, área e espessura do osso cortical e trabecular em fêmur de ratos. Este foi um estudo experimental no qual foram utilizados 18 ratos Wistar machos, com 40 dias de vida, pesando 179 $\pm 2,5 \mathrm{~g}$. Os ratos foram divididos em três grupos ( $\mathrm{n}=06)$ : CT (controle), AC (alcoolista crônico), e DT (desintoxicado). Após os procedimentos experimentais os animais foram eutanaziados por uma overdose de anestésico e os fêmures coletados para os testes mecânicos e processamento histológico. Todos os animais não apresentaram desnutrição ou desidratação durante o período de experimentação. As análises morfométrica do osso cortical e trabecular demonstraram que os animais do grupo AC apresentavam dimensões inferiores, enquanto nos animais do grupo DT observou-se um aumento na área e espessura do osso cortical e trabecular. Dados dos materiais e das propriedades estruturais óssea do grupo AC destacam os efeitos nocivos do etanol sobre as propriedades mecânicas do osso. Os resultados deste estudo demonstraram que os ratos do grupo AC apresentaram danos significativos no osso em todas as variáveis analisadas. Esses resultados sugerem que a desintoxicação alcoólica é recomendada no planejamento pré-operatório e isso corrobora para o sucesso de cirurgias e reparação no tecido ósseo. Agradecemos ao apoio financeiro oferecido pelo PROBIC - UNIFENAS.

Palavras-chave: etanol, ratos, osso, alcoolismo, desintoxicação. 


\section{Introduction}

The main component of alcoholic beverages is ethanol, the substance responsible for chemical addiction and for a chronic, progressive disease, the alcoholism. Ethanol acts as a toxic element to vital organs, performing harmful effects on resistant tissues, as bones. Therefore, alcohol consumption is prejudicial to bone tissue integrity and hence, it can difficult bone repair after traumatic injuries (Lima et al., 2011).

Alcoholism is a risk factor for bone fractures and osteoporosis, whose pathogenesis remains uncertain (Santori et al., 2008). Not only the ethanol damages bone structure, but also factors such as vitamin D deficiency and improper eating habits, characteristic of alcoholics, become causes of aggression to bone tissue (González-Reimers et al., 2011). Experimental studies demonstrated that the consumption of ethanol in different concentrations ( 5 to $20 \%$ ) caused morphological alterations in trabecular bone, volume, repair and biomechanical alterations in bone tissue (Lima et al., 2011; Horvath et al., 2010; Soares et al., 2010). Preoperative guidelines involving surgical bone procedures, as orthopedics or orthodontic practice, discuss about the patient's need to eliminate or minimize alcoholic beverage consumption. This statement seeks the reduction of organs exposure to ethanol, what will help in bone tissue repair and aid to reduce the risk of infections. The effects of alcohol detoxification on bone tissue biomechanics and repair, however, has been poorly investigated until the present date.

Considering the great number of alcoholics individuals, the relationship between ethanol consumption and bone fragility the aim of this study is to evaluate the effects of ethanol consumption and alcohol detoxification on the biomechanics, area and thickness of cortical and trabecular bone in rat femurs.

\section{Material and Methods}

\subsection{Animal protocol}

After approval by the Committee of Ethics in Research of Universidade José do Rosário Vellano (UNIFENAS), Protocol no. 19A/2007. The study subjects were 18 male Wistar rats (Rattus norvegicus) at 40 days of age, weighing $179 \pm 2,5 \mathrm{~g}$, and kept with temperature control and 12-hour control in the light/dark cycle. They were divided into three random groups $(n=6)$ : Control Group (CT): The animals received water ad libitum; Chronic Alcoholic Group (AC): These animals followed the model of chronic alcoholism determined "semivoluntary" where ethyl alcohol (99.9\% - Merck $^{\circledR}$ ) was diluted with water, this being the only liquid food available for the animals. The animals first underwent a brief period of gradual adaptation to alcohol, receiving a $0 \%, 5 \%$ and $10 \%$ ethyl alcohol based liquid diet for two weeks, and in the third week $15 \%$ ethyl alcohol, continuing with this diet until the fourteenth week, following the protocol proposed by Cagnon et al. (1993) and Horvath et al. (2010). Detoxification Group (DT):
This group was submitted to the same protocol as the AL group. However, upon completion of the fourth week of $15 \%$ ethanol ingestion, the animals started the period of gradual alcohol re-adaptation, receiving a 10\%, 5\% and a $0 \%$ ethyl alcohol based liquid diet for one week each, and a liquid diet on a basis of water ad libitum until the $14^{\text {th }}$ week, when they were considered detoxified (Table 1).

All animals received the same solid diet $\left(\right.$ Nuvilab $\left.^{\circledR}\right)$ and in every 48 hours of the experimental procedures, fresh water or new dilutions of ethanol were offered. At these moments, the animals were weighted and the consumption of solid and liquid diet were measured to calculate average caloric ingestion. Both, solid and liquid diet, were administrated ad libitum. The liquid diet was offered through bottles. Upon completing 14 weeks of experiment the animals were anesthetized then euthanized with an overdose of anesthesia, administered intraperitoneally (IP), using xylazine/ketamine (Francotar ${ }^{\circledR}$, Virbaxyl $^{\circledR} 2 \%$ ) in the concentration of 6 and $40 \mathrm{mg} / \mathrm{Kg}$, respectively.

\subsection{Femur morphometry}

\subsubsection{Anatomical measurements of the femur}

After removal of all soft tissue from the femurs, the following four measurements were obtained with a digital caliper and magnifying glass according to Lammers et al. (1998): 1) femur length (measured from the most proximal point of the femoral head to the most distant end of the femur); 2) width of the femoral diaphysis (measured at the narrowest point of the mid-femur); 3) width of the proximal femur (measured from the anterior point of the femoral head to the tip of the greater trochanter); 4) width of the distal femur (corresponding to the width of the condyle in the anteroposterior direction perpendicular to the length of the femur).

\subsubsection{Epiphyseal trabecular bone}

The distal epiphysis of the femur was used for this analysis. Six histological sections were prepared for each femur and two fields of each section were captured. The specimens were fixed in $10 \%$ buffered formalin for $72 \mathrm{~h}$ and decalcified in a solution of formic acid, formalin and sodium citrate for 35 days. Next, the specimens were submitted to routine histological processing and embedded in paraffin. Longitudinal sections $(5 \mu \mathrm{m})$ were obtained and stained with hematoxylineosin. The histological sections

Table 1. Protocol experiment.

\begin{tabular}{|c|c|c|c|}
\hline Group & \multicolumn{3}{|c|}{ Protocol experiment } \\
\hline & 4 weeks & 6 weeks & 4 weeks \\
\hline $\mathrm{CT}$ & Water & Water & Water \\
\hline $\mathrm{AC}$ & $\begin{array}{c}\text { Ethanol } \\
(0,5,10 \text { and } \\
15 \%)^{*}\end{array}$ & $\begin{array}{c}\text { Ethanol } \\
(15 \%)\end{array}$ & $\begin{array}{c}\text { Ethanol } \\
(15 \%)\end{array}$ \\
\hline DT & $\begin{array}{c}\text { Ethanol } \\
(0,5,10 \text { and } \\
15 \%)^{*}\end{array}$ & $\begin{array}{c}\text { Ethanol } \\
(15 \%)\end{array}$ & $\begin{array}{c}\text { Ethanol } \\
(10,5 \text { and } \\
0 \%)^{* *}\end{array}$ \\
\hline
\end{tabular}

*Period of adaptation. **Period of detoxication. 
were examined under a Nikon 80i photomicroscope using a 20x objective. The images were captured with a Nikon DS-Ri1 camera for the analysis of trabecular bone area, area fraction and mean thickness using the NISElements 3.0 Advanced Research software (Nakagaki et al., 2011).

\subsubsection{Diaphyseal cortical bone}

The middle third of the femoral diaphysis was used for this analysis. Cross-sections $(5 \mu \mathrm{m})$ were obtained and stained with hematoxylin-eosin. Twelve histological sections $(1$ section $=1$ field $)$ were prepared for each bone. The images were captured using a $4 \mathrm{x}$ objective and the cortical bone area (cross-section area - medullary area) and mean cortical thickness were calculated (Nakagaki et al., 2011).

\subsection{Mechanical test}

The animals' right femurs were removed and stored in a freezer $\left(-20^{\circ} \mathrm{C}\right)$ until the day prior to the mechanical test (Nakagaki et al., 2011; Soares et al., 2012). For the mechanical test, femurs ( $\mathrm{n}=06$ per group) were submitted to three-point bending testing until complete fracture at a velocity of $3 \mathrm{~mm} / \mathrm{min}$. An MTS TestStar II apparatus with a load cell of $100 \mathrm{Kgf}$ was used.

Each femur was tested in the anteroposterior plane (concave-up position), with the anterior surface of the bone facing upwards. The load and displacement data were obtained directly from the MTS system and recorded with a computer coupled to the testing machine. These data were used for the acquisition and calculation of the structural properties: maximum load, displacement at maximum load, and extrinsic stiffness. The extrinsic stiffness was calculated as the slope of the most linear portion of the elastic region of the load-displacement curve (Akhter et al., 2001; Huang et al., 2003). After testing of the specimens in three-point bending, the failure sites of all bone specimens were photographed, together with a measurement standard, by a highresolution digital camera at a standardized distance according to Huang et al. (2003). The parameters of cross-sectional cortical bone area of the diaphysis were measured on the images using the NIS-Elements 3.0 software (Advanced Research, USA). The crosssectional moment of inertia (CSMI) at the point of failure was calculated by the method of Turner and Burr (1993), (Equation 1).

$I=\frac{\partial}{64}\left[a b^{3}-(a-2 t)(b-2 t)^{3}\right]$

Where $I$ is the CSMI, $a$ is the width of the cross-sectional area in the mediolateral direction, $b$ is the width of the cross-sectional area in the anteroposterior direction and $t$ is the average cortical thickness (Turner and Burr, 1993). The material properties were obtained from the structural properties (Akhter et al., 2001). The following material properties were evaluated: maximum stress, strain at maximum stress and elastic modulus. On the basis of the load-displacement data, these parameters were calculated using equation models (Equations 1, 2 and 3).

$$
\begin{aligned}
& \sigma=\frac{f_{\text {or } c ̧ a} \cdot L \cdot \leq c}{4 I} \\
& \varepsilon=\frac{12 \cdot c \cdot d}{L^{2}}
\end{aligned}
$$

$$
E=\frac{\text { rigidez } \cdot L^{3}}{48 I}
$$

Where $\sigma$ is the stress, $L$ is the distance between the two lower supports, $c$ is the maximum distance from pixels to the line that crosses the center of the mass, $\mathrm{E}$ is the strain, $d$ is the displacement, and $E$ is the elastic modulus (Equation 4).

\subsection{Statistical analysis}

Final weight (g), daily fluid intake (ml), daily solid intake $(\mathrm{g})$, laboratory analysis, biomechanical analysis of the femurs, the morphological and morphometric comparison were statistically compared among the groups by analysis of variance followed by the Tukey's test, with the level of significance set at 1 and $5 \%$, respectively. Means with different letters were significantly different $(5 \%)$ from each other.

\section{Results}

The liquid and solid consumption was satisfactory among the groups, yet the animals from the AC and DT groups ingested a smaller amount of the liquid diet than the animals from the CT groups (Table 2). Solid diet consumption was lower in the animals from the DT group than in the animals from the $\mathrm{CT}$ and AC groups (Table 2). During the experiment the animals gained weight, and there were no significant differences among the experimental groups (Table 2).

The analysis of the dimensions of femurs revealed that animals of groups CT, AC and DT did not differ for the femur length, width of the proximal femur, femoral shaft width and breadth of the distal femur (Table 3). Measurement of trabecular area and cortical thickness of CT group presented superior values when compared to $\mathrm{AC}$ and DT groups (Table 3; Figures 1 and 2). Trabecular thickness of AC group were inferior than $\mathrm{CT}$ and DT groups (Table 3; Figures 1 and 2). Trabecular thickness of CT group is approximately $21 \%$ wider than trabecules from AC group (Table 3; Figures 1 and 2).

Table 2. Comparison of weight gain $(\Delta)$; consumption of liquid and solid diet in the control groups (CT), chronic alcoholic (AC) and detoxification (DT) groups.

\begin{tabular}{lccc}
\hline \multicolumn{1}{c}{ Variable } & CT & AC & DT \\
\hline $\mathrm{N}$ & 06 & 06 & 06 \\
$\Delta \mathrm{P}(\mathrm{g})$ & $289 \pm 2.1^{\mathrm{a}}$ & $283 \pm 1.2^{\mathrm{a}}$ & $281 \pm 1.2^{\mathrm{a}}$ \\
Solid intake $(\mathrm{g})$ & $42 \pm 0.6^{\mathrm{a}}$ & $42 \pm 0.5^{\mathrm{a}}$ & $40 \pm 1.5^{\mathrm{b}}$ \\
Fluid intake $(\mathrm{mL})$ & $59 \pm 1.3^{\mathrm{a}}$ & $45 \pm 0.6^{\mathrm{b}}$ & $47 \pm 0.6^{\mathrm{b}}$ \\
\hline
\end{tabular}

Two averages, followed by the same small letter are not different to each other $(\mathrm{P}>0.05)$ Tukey's test. Results are reported as the mean \pm standard deviation. 
Table 3. Morphometric parameters obtained for animals of groups CT, AC e DT.

\begin{tabular}{|c|c|c|c|}
\hline Medida & CT & $\mathbf{A C}$ & DT \\
\hline FL (mm) & $23.3 \pm 0.4^{\mathrm{a}}$ & $23.5 \pm 0.3^{\mathrm{a}}$ & $23.2 \pm 0.3^{\mathrm{a}}$ \\
\hline PW (mm) & $.0 \pm 0.10^{\mathrm{a}}$ & $8.8 \pm 0.10^{\mathrm{a}}$ & $8.7 \pm 0.10^{\mathrm{a}}$ \\
\hline WDia (mm) & $6.4 \pm 0.2^{\mathrm{a}}$ & $6.0 \pm 0.2^{\mathrm{a}}$ & $6.2 \pm 0.1^{\mathrm{a}}$ \\
\hline DW (mm) & $7.8 \pm 0.16^{\mathrm{a}}$ & $7.7 \pm 0.17^{\mathrm{a}}$ & $7.7 \pm 0.16^{\mathrm{a}}$ \\
\hline TA $\left(\mathrm{mm}^{2}\right)$ & $14.5 \pm 0.2^{\mathrm{a}}$ & $10.6 \pm 0.1^{\mathrm{b}}$ & $11.5 \pm 0.1^{\mathrm{b}}$ \\
\hline TT (mm) & $1.2 \pm 0.02^{\mathrm{a}}$ & $0.95 \pm 0.15^{b}$ & $1.1 \pm 0.02^{\mathrm{a}}$ \\
\hline $\mathrm{CA}\left(\mathrm{mm}^{2}\right)$ & $23.2 \pm 0.1^{\mathrm{a}}$ & $17.3 \pm 0.15^{b}$ & $18 \pm 0.14^{b}$ \\
\hline $\mathrm{CT}(\mathrm{mm})$ & $3.9 \pm 0.02^{\mathrm{a}}$ & $2.3 \pm 0.01^{\mathrm{b}}$ & $2.4 \pm 0.01^{\mathrm{b}}$ \\
\hline
\end{tabular}

FL: femur length; PW: proximal femur width: WDia: femur width at the diaphysis; DW: distal femur width; TA: trabecular area; TT: trabecular thickness; CA: cortical area; CT: cortical thickness. Results are reported as the mean \pm standard deviation. Two means followed by the same superscript letter did not differ from one another $(p>0.05$, Tukey test).
Table 4. Structural and material properties of the femurs of rats of groups CT, AC and DT.

\begin{tabular}{|c|c|c|c|}
\hline $\begin{array}{c}\text { Mechanical } \\
\text { properties }\end{array}$ & CT & $\mathrm{AC}$ & DT \\
\hline $\begin{array}{l}\text { Maximum load } \\
\text { (N) }\end{array}$ & $169 \pm 35^{\mathrm{a}}$ & $102 \pm 19^{b}$ & $145 \pm 15^{\mathrm{c}}$ \\
\hline $\begin{array}{l}\text { Displacement } \\
(\mathrm{mm})\end{array}$ & $0,68 \pm 0,3^{\mathrm{a}}$ & $0,42 \pm 2,3^{b}$ & $0,6 \pm 0,3^{\mathrm{a}}$ \\
\hline $\begin{array}{l}\text { Stiffness } \\
(\mathrm{N} / \mathrm{mm})\end{array}$ & $112.0 \pm 17.7^{\mathrm{a}}$ & $35.19 \pm 8.3^{\mathrm{b}}$ & $92.0 \pm 57.56^{\mathrm{a}}$ \\
\hline $\begin{array}{l}\text { Maximum } \\
\text { stress }(\mathrm{MPa})\end{array}$ & $26.0 \pm 7.0^{\mathrm{a}}$ & $16.8 \pm 2.1^{\mathrm{b}}$ & $25.7 \pm 6.9^{\mathrm{a}}$ \\
\hline $\begin{array}{l}\text { Elastic } \\
\text { modulus }(\mathrm{MPa})\end{array}$ & $80.3 \pm 40^{\mathrm{a}}$ & $29.0 \pm 8.70^{\mathrm{b}}$ & $83 \pm 42^{\mathrm{a}}$ \\
\hline Strain $(\mathrm{MPa})$ & $0.15 \pm 0.01^{\mathrm{a}}$ & $0.28 \pm 0.07^{\mathrm{b}}$ & $0.22 \pm 0.10^{\mathrm{a}}$ \\
\hline
\end{tabular}

Results are reported as the mean \pm standard deviation. Two means followed by the same superscript letter did not differ from one another ( $p>0.05$, Tukey test).
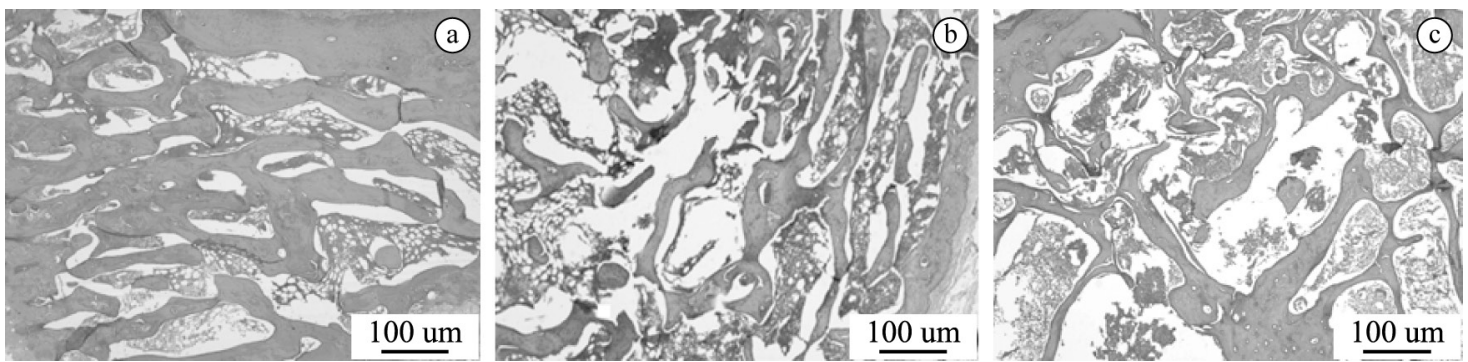

Figure 1. Photomicrographs of cross-sections of the femur showing trabecular bone in distal femoral epiphysis of groups CT (a), AC (b) and DT (c). Hematoxylin-eosin staining. (5x objective).
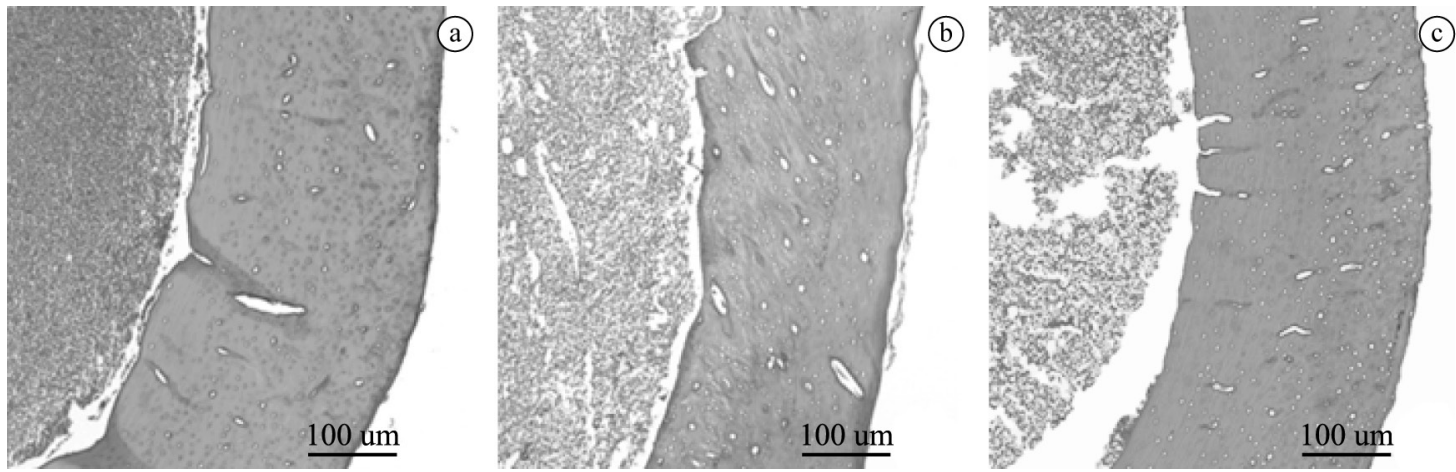

Figure 2. Photomicrographs of cross-sections of femoral diaphysis of groups CT (a), AC (b) and DT (c). Hematoxylin-eosin staining. (10x objective).

The result obtained from mechanic assay demonstrated that the maximum load required to complete fracture of femurs was smaller in AC group, followed by DT and CT group, the more resistant (Table 4). Stiffness analysis of femurs of groups CT and DT were comparable and superiors from values of AC group (Table 4).

In the material property analysis, the data demonstrated that maximum stress of femurs of CT and DT groups did not present any significant differences. Ethanol consumption led to modifications in maximum stress of AC group (Table 4). Elastic modulus analysis and strain values of AC and DT group were inferior than CT group (Table 4).

\section{Discussion}

During all experimentation period, rats of CT, $\mathrm{AC}$ and DT groups had a gain of weight and also proper liquid and food intake. The control of liquid and food intake and during 
experimentation period was essential, because a low food ingestion can lead to protein malnutrition and a small liquid drinking is directly associated to dehydration, misleading the experimental results (Holbrook and Connor, 1993). Malnutrition associated with vitamin, mineral and essential nutrients deficiency is frequent in alcoholic individuals (Moreno and Cortés, 2008). In this way, morphologic and biomechanic alterations observed in animals of $\mathrm{AC}$ and DT groups were directly related to the harmful effects of ethanol consumption, since rats did not present dehydration or malnutrition, confirmed by weight gain.

Different methodologies, demonstrated with various alcohol concentration and time of exposure were used to evaluate the effects of ethanol in bone tissue. The protocol used in the present study was satisfactory to cause bone alterations, and this it did not cause overdose or death of any animal. Previous studies about experimental alcoholism used ethanol concentration ranging between 10 and $30 \%$, in time periods of four to twelve weeks (Horvath et al., 2010; Soares et al., 2010; Camilli et al., 2004). In bone tissue, as well as in other tissues, alcohol concentration is low, but the modifications occur as the exposure time is prolonged (Yttri et al., 2004).

Animal studies about the abusive use of alcohol suggested that ethanol inhibits bone growth (Lewiecki, 2008). Regarding bone growth, the present study did not detect any differences in femurs dimensions of CT, AC and DT groups.

Ethanol consumption makes individuals more likely to suffer fractures, as a result of direct and indirect effects on bone tissue, as well due to the lack of balance and alterations in central nervous system, leading to a greater tendency of falling or stumbling (Balzan et al., 2001). Geometric characteristics of cortical and trabecular bones as thickness and area are directly related to bone resistance and fractures (Epstein, 2007). Reduction in area and thickness of trabecular bone is observed in imaging of patients with osteoporosis (Leite et al., 2008). Previous study (Iwaniec et al., 2008) showed that the ethanol consumption reduced trabecular bone, cortical bone formation and bone density. Analysis of cortical thickness, cortical area and trabecular area of AL group suggest that femurs of those animals are more susceptible to fractures. The analysis of the same variables of DT groups demonstrated that the elimination of ethylic tendency results in an improvement of bone metabolism, as this group presented morphometric parameters of cortical and trabecular bones superior to AC group. Chronic ethanol consumption induces a bone mineral composition modification, making them more fragile and prone to fractures (Soares et al., 2010). Alcohol detoxification is efficient, because it enhances osteogenesis, osteointegration, calcemia and bone mechanical resistance (Horvath et al., 2010).

Mechanical assays frequently used for determining the mechanical properties of cortical bone are traction assay, compression, flexion in three or four points, twisting, pure shear, fatigue and micro or nanoidentation (Kruzic and Ritchie, 2008). In our study we decided to make a three point flexion test, evaluating the material and structural properties of femurs. Ethanol modifies bone mineral composition, as well the mechanical properties of bones, making it more fragile and likely to fracture (Soares et al., 2010). Mechanical testing of AC group femurs demonstrated the harmful effect of ethanol consumption, because the animals presented modifications in structural and material properties of bones, making it more fragile.

Ruppel et al. (2008), suggest that a reduction of mineral matrix can increase bone fragility, affecting mainly the bone tissue mechanical properties. Calcium is an important mineral bone component and its bone level alteration is associated with a decrease in elastic modulus (Burstein et al., 1975). Femurs of animals of AC group presented alterations in elastic modulus, demonstrating that ethanol consumption made the bone less elastic. Animals of DT group showed elastic modulus similar to CT group, suggesting that alcohol detoxification leads to bone metabolic benefits.

Hernandez et al. (2001), observed that the low mineralization rate is associated to low stiffness and bone resistance. In the analysis of extrinsic stiffness, the maximum stress and femur deformation were more compromised in AC group. When the ethylic habit was eliminated (DT group), those bone properties were similar to the parameters found in (CT group).

The results of the present study demonstrated that chronic alcoholic animals showed major bone compromises in all analyzed variables. Also stopping the alcoholic intake reversed some of those variables. The morphology and biomechanics analysis of the femurs of detoxified animals showed higher than values observed in the alcoholic group, suggesting that the alcoholic habit disposal must be shown in order to minimize the risk of bone fractures. This study highlights a significant factor related to the process of alcoholic detoxification in surgical situations involving bone repair and its biomechanical structures clinical planning.

\section{References}

AKHTER, M.P., CULLEN, D.M., GONG, G. and RECKER, R.R., 2001. Bone biomechanical properties in prostaglandin EP1 and EP2 knockout mice. Bone, vol. 29, no. 2, pp. 121-125. http:// dx.doi.org/10.1016/S8756-3282(01)00486-0. PMid:11502472.

BALZAN, S.M.P., MEDEIROS, L.R., PIONNER, S.R., MAFFAZZIOLI, L. and ZYLBERSTEIN, S., 2001. Osteoporose e álcool. Jornal Brasileiro de Medicina, vol. 80, no. 4, pp. 60-64.

BURSTEIN, A.H., ZIKA, J.M., HEIPLE, K.G. and KLEIN, L., 1975. Contribution of collagen and mineral to the elastic-plastic properties of bone. The Journal of Bone and Joint Surgery. American Volume, vol. 57, no. 7, pp. 956-961. PMid:1184645.

CAGNON, V.H., GARCIA, P.J., MARTINEZ, F.E., MARTINEZ, M. and PADOVANI, C.R., 1993. Ultrastructural study of the ventral lobe of the prostate of rats submitted to experimental chronic alcoholism. The Prostate, vol. 22, no. 4, pp. 317-324. http://dx.doi.org/10.1002/pros.2990220406. PMid:8497427. 
CAMILLI, J.A., CUNHA, M.R., BERTRAN, C.A. and KAWACHI, E.Y., 2004. Subperiosteal hydroxyapatite implants in rats submitted to ethanol ingestion. Archives of Oral Biology, vol. 49, no. 9, pp. 747-753. http://dx.doi.org/10.1016/j.archoralbio.2004.02.009. PMid:15275862

EPSTEIN, S., 2007. Is cortical bone hip? What determines cortical bone properties? Bone, vol. 41, no. 1, suppl. 1, pp. 3-8. http://dx.doi.org/10.1016/j.bone.2007.03.006. PMid:17466615.

GONZÁLEZ-REIMERS, E., ALVISA-NEGRÍN, J., SANTOLARIAFERNÁNDEZ, F., CANDELARIA MARTÍN-GONZÁLEZ, M., HERNÁNDEZ-BETANCOR, I., FERNÁNDEZ-RODRÍGUEZ, C.M., VIÑA-RODRIGUEZ, J. and GONZÁLEZ-DÍAS, A., 2011. Vitamin D and nutritional status are related to bone fractures in alcoholics. Alcohol and Alcoholism, vol. 46, no. 2, pp. 148-155. http://dx.doi.org/10.1093/alcalc/agq098. PMid:21248027.

HERNANDEZ, C.J., BEAUPRÉ, G.S., KELLER, T.S. and CARTER, D.R., 2001. The influence of bone volume fraction and ash fraction on bone strength and modulus. Bone, vol. 29, no. 1, pp. 74-78. http://dx.doi.org/10.1016/S8756-3282(01)00467-7. PMid:11472894

HOLBROOK, T.L. and CONNOR, E.B., 1993. A prospective study of alcohol consumption and bone mineral density. British Medical Journal, vol. 306, no. 6891, pp. 1506-1509. http://dx.doi. org/10.1136/bmj.306.6891.1506. PMid:8518677.

HORVATH, R.O., SILVA, T.D., CALIL-NETO, J., NAKAGAKI, W.R., GARCIA, J.A.D. and SOARES, E.A., 2010. Efeitos do alcoolismo e da desintoxicação alcoólica sobre o reparo e biomecânica óssea. Acta Ortopedica Brasileira, vol. 19, no. 5, pp. 305-308. http://dx.doi.org/10.1590/S1413-78522011000500008.

HUANG, T.H., LIN, S.C., CHANG, F.L., HSIEH, S.S., LIU, S.H. and YANG, G.R.S., 2003. Effects of different exercise modes on mineralization, structure, and biomechanical properties of growing bone. Journal of Applied Physiology, vol. 95, no. 1, pp. 300-307. http://dx.doi.org/10.1152/japplphysiol.01076.2002. PMid:12611764

IWANIEC, U.T., TREVISIOL, C.H., MADDALOZZO, G.F., ROSEN, C.J. and TURNER, R.T., 2008. Effects of low-dose parathyroid hormone on bone mass, turnover, and ectopic osteoinduction in a rat model for chronic alcohol abuse. Bone, vol. 42, no. 4, pp. 695-701. http://dx.doi.org/10.1016/j.bone.2007.12.221. PMid:18295560.

KRUZIC, J.J. and RITCHIE, R.O., 2008. Fatigue of mineralized tissues: cortical bone and dentin. Journal of the Mechanical Behavior of Biomedical Materials, vol. 1, no. 1, pp. 3-17. http:// dx.doi.org/10.1016/j.jmbbm.2007.04.002. PMid:19627767.

LAMMERS, A.R., GERMAN, R.Z. and LIGHTFOOT, P.S., 1998. The impact of muscular dystrophy on limb bone growth and scaling in mice. Acta Anatomica, vol. 162, no. 4, pp. 199-208. http://dx.doi.org/10.1159/000046435. PMid:9831769.

LEITE, A.F., FIGUEIREDO, P.T.S., GUIA, C.M., MELO, N.S. and PAULA, A.P., 2008. Radiografia panorâmica: instrumento auxiliar no diagnóstico da osteoporose. Revista Brasileira de
Reumatologia, vol. 48, no. 4, pp. 226-233. http://dx.doi.org/10.1590/ S0482-50042008000400006.

LEWIECKI, E.M., 2008. Prevention and treatment of postmenopausal osteoporosis. Obstetrics and Gynecology Clinics of North America, vol. 35, no. 2, pp. 301-315. http://dx.doi.org/10.1016/j. ogc.2008.03.007. PMid:18486843.

LIMA, C.C., SILVA, T.D., SANTOS, L., NAKAGAKI, W.R., LOYOLA, Y.C.S., RESCK, M.C., CAMILLI, J.A., SOARES, E.A. and GARCIA, J.A., 2011. Effects of ethanol on the osteogenesis around porous hydroxyapatite implants. Brazilian Journal of Biology $=$ Revista Brasileira de Biologia, vol. 71, no. 1, pp. 115-119. http://dx.doi.org/10.1590/S1519-69842011000100017. PMid:21437407

MORENO, O.R. and CORTÉS, J.R., 2008. Nutrition and chronic alcohol abuse. Nutricion Hospitalaria, vol. 23, suppl. 2, pp. 3-7. PMid: 18714405.

NAKAGAKI, W.R., BERTRAN, C.A., MATSUMURA, C.Y., SANTO-NETO, H. and CAMILLI, J.A., 2011. Mechanical biochemical and morphometric alterations in the femur of $\mathrm{mdx}$ mice. Bone, vol. 48, no. 2, pp. 372-379. http://dx.doi.org/10.1016/j. bone.2010.09.011. PMid:20850579.

RUPPEL, M.E., MILLER, L.M. and BURR, D.B., 2008. The effect of the microscopic and nanoscale structure on bone fragility. Osteoporos, vol. 19, no. 9, pp. 1251-1265. http://dx.doi. org/10.1007/s00198-008-0579-1. PMid:18317862.

SANTORI, C., CECCANTI, M., DIACINTI, D., ATTILIA, M.L., TOPPO, L., D'ERASMO, E., ROMAGNOLI, E., MASCIA, M.L., CIPRIANI, C., PRASTARO, A., CARNEVALE, V. and MINISOLA, S., 2008. Skeletal turnover, bone mineral density, and fractures in male chronic abusers of alcohol. Journal of Endocrinological Investigation, vol. 31, no. 4, pp. 321-326. http:// dx.doi.org/10.1007/BF03346365. PMid:18475050.

SOARES, E.A., FAVARO, W.J., CAGNON, V.H.A., BERTRAN, C.A. and CAMILLI, J.A., 2010. Effects of alcohol and nicotine on the mechanical resistance of bone and bone neoformation around hydroxyapatite implants. Journal of Bone and Mineral Metabolism, vol. 28, no. 1, pp. 101-107. http://dx.doi.org/10.1007/ s00774-009-0115-1. PMid:19669082.

SOARES, E.A., NAKAGAKI, W.R., GARCIA, J.A. and CAMILLI, J.A., 2012. Effect of hyperlipidemia on femoral biomechanics and morphology in low-density lipoprotein receptor gene knockout mice. Journal of Bone and Mineral Metabolism, vol. 30, no. 4, pp. 419-425. http://dx.doi.org/10.1007/s00774-011-0345-x. PMid:22246084

TURNER, C.H. and BURR, D.B., 1993. Basic biomechanical measurements of bone: a tutorial. Bone, vol. 14, no. 4, pp. 595-608. http://dx.doi.org/10.1016/8756-3282(93)90081-K. PMid:8274302.

YTTRI, E.A., BURK, J.A. and HUNT, P.S., 2004. Intermittent ethanol exposure in adolescent rats: dose-dependent impairments in trace conditioning. Alcoholism, Clinical and Experimental Research, vol. 28 , no. 10, pp. 1433-1436. http://dx.doi.org/10.1097/01. alc.0000147657.51745.a7. PMid:15597074 